\title{
Novos datos sobre a arte rupestre no Miño litoral. 0 concello de As Neves (Pontevedra)
}

New data about rock arte in Miño litoral. As Neves municipality (Pontevedra)

http://dx.doi.org/10.15304/gall.38.5948

Xurxo Pereira Martínez

Universidade de Santiago de Compostela

arratsaguarda@gimail.com

Ramón Fábregas Valcarce

Grupo de Estudio para la Prehistoria del Noroeste Ibérico (GEPN-AAT)

Universidade de Santiago de Compostela

ramonfabregas@gmail.com

\section{Resumo}

Recentes traballos realizados no concello das Neves veñen a aportar novos datos sobre a arte rupestre nesta zona do Miño. Así, coas novas prospeccións incrementouse considerablemente o número de estacións rupestres coñecidas ata o de agora, con respecto ás recollidas na Dirección Xeral de Patrimonio Cultural, o que nos leva a pensar nunha distribución máis ampla dos gravados de arte rupestre atlántica e de alogúns dos seus motivos.

Palabras Chave: Petróglifos, prospección, arte rupestre, val do Miño

\section{Summary}

Recent works performed in the As Neves Council have become a valuable source of new data on rock art in this area of the Miño. Thus, with these new surveys the number of petroglyphs known up to now has come to a considerable increase, in regards to those that were previously collected in the Dirección Xeral de Patrimonio Cultural, which leads us to believe in a wider distribution of the atlantic rock art and some of its motifs.

Keywords: Petroglyphs, survey, rock art, Minho valley. 


\section{INTRODUCIÓN E OBXECTIVOS}

A investigación arqueolóxica tivo pouco desenvolvemento -no contexto da historiografía arqueolóxica galega- na rexión que nos ocupa, se ben nalgunhas ocasións tívose en consideración a zona, como por exemplo para a arte rupestre, Peña Santos e García Alén (1981), Barciela e Rey (2000) ou Tamuxe e Martínez Barbosa (2008). Para o caso que nos ocupa, o estudo dos petróglifos, o coñecemento da súa distribución espacial en Galicia obedece en grande medida á desigual atención prestada entre as diferentes zonas do país. Así, novos traballos que tentaron facer unha aproximación ao número de estacións de arte rupestres en Galicia (VÁZQUEZ, FÁBREGAS \& RODRÍGUEZ-RELLÁN 2016; VÁZQUEZ, RODRÍGUEZ-RELLÁN \& FÁBREGAS 2018) confirmaron a visión tradicional sobre a distribución desigual e concentrada da arte rupestre.Neste senso, obsérvase una maior densidade na parte occidental de Galicia, e polo tanto, as investigacións fóra das principais áreas de distribución deste fenómeno poden axudar a entender mellor a dinámica e diversidade dos petróglifos no noroeste peninsular.

O principal obxectivo desde traballo é realizar, de xeito conciso, unha primeira aproximación o novo conxunto de gravados rupestres localizados no concello das Neves (Pontevedra), e que supoñen unha novidade nesta parte do territorio galego. Con todo, cómpre sinalar que este traballo artéllase nun marco territorial determinado, a escala administrativa, e polo tanto non pretende realizar interpretacións de alcance global. Con todo os resultados poden axudar a mellor comprensión dun fenómeno tan dispar como o da arte rupestre ao aire libre no noroeste peninsular.

\section{MARCO TERRITORIAL E METODOLOXÍA}

O concello das Neves sitúase na provincia de Pontevedra, na comarca do Condado, e conta con importantes referentes xeográficos. Limitado ao sur polo río Miño, e o noroeste polos montes do Paradanta, esta zona conta con importantes áreas de val, como a do río Termes, do río Xuliana, ou a que forma o propio Miño. Outro referente xeográfico de importancia é o monte San Nomedio, situado na parroquia de San Xosé de Ribarteme e Taboexa e que chega case ós 700 metros de altitude.

Este espazo escolleuse para levar a cabo os estudos no ámbito da arte rupestre ó aire libre. Porén, antes de comezar coas prospeccións procedeuse ao baleirado dos datos das fichas de inventario da Dirección Xeral de Patrimonio Cultural (DXPC), así como un estudo da bibliografía existente sobre o tema nesta zona.

Os datos obtidos na DXPC mostraban un total de 27 superficies de arte rupestre inventariadas, un número bastante escaso se o comparamos con outras áreas do sur de Pontevedra, como Oia, ou o Val Miñor. Por outra parte, os estudos centrados noutros territorios do Miño litoral revelaron que o número de superficies inventariadas pouco tiña que ver coa realidade unha veza zona (VÁZQUEZ 2016). Unha problemática engadida a nosa área de estudo e que apenas existen -como xa sinalamos- traballos que sobre arte rupestre neste territorio. 


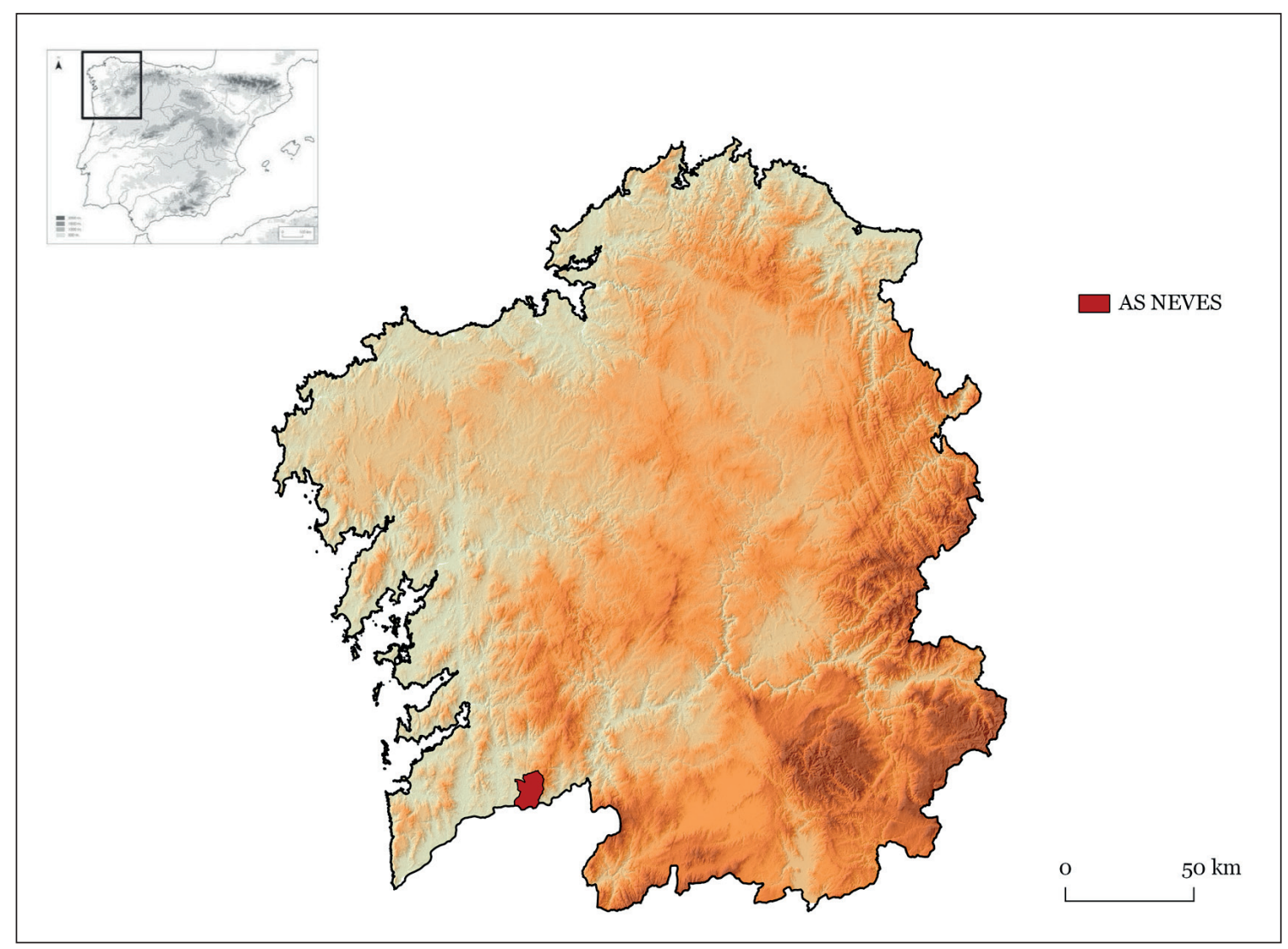

Figura 1. Área de estudo.

Recentes propostas sobre a distribución espacial dos petróglifos galegos (RODRÍGUEZ-RELLÁN, FÁBREGAS, \& VÁZQUEZ 2018) mostraron, a través de diversas análises, diferentes agrupacións de estacións rupestres para o territorio galego. Os principais clusteres identificados foron oito: A Península del Barbanza, a área de Carnota-Muros, o Baixo Miño e Vigo, Carballiño, Campo Lameiro-Morrazo, o Deza, Betanzos e por último, a comarca do Condado.

A esta última agrupación pertence a nosa área de estudo, que dentro do propio cluster analizado non supuña - no momento do estudo - un gran aporte no número de estacións rupestres, nin a nivel cuantitativo nin a nivel cualitativo. Porén, tralo traballo de campo realizado puidemos observar como o número de estacións rupestres aumentou de xeito considerable, chegando ás 119 superficies con gravados no concello de As Neves, o que supón un incremento de ata un $77,3 \%$ con respecto aos datos coñecidos.

Para definir unha "estación rupestre", seguiremos en grande medida a metodoloxía empregada por Rodríguez Rellán et al. (2018), establecendo como parte dos mesmos paneis de arte rupestre aquelas superficies que constitúan o mesmo afloramento. Ademais, consideramos que tamén conforman a mesma estación ou grupo, aquelas superficies con gravados que se sitúen a menos de 2 metros de distancia. Para unha maior precisión, dentro da propia estación rupestre estableceuse unha subdivisión por número de rochas para facilitar o rexistro e clasificación dos datos de tódalas superficies.

Durante o traballo de campo foron analizadas tamén as superficies xa catalogadas na DXPC, ou as recollidas pola bibliografía da zona, para facer a revisión das mesmas. 
Ademais, debemos sinalar que se desenvolveron labores de rexistro e limpeza de varias estacións rupestres na zona (MÉNDEZ 2018), das que se tivo constancia durante o desenvolvemento das prospeccións, e que foron incluídas na realización do traballo.

Figura 2. Distribución das estacións de arte rupestre a través dos datos da DXPC.

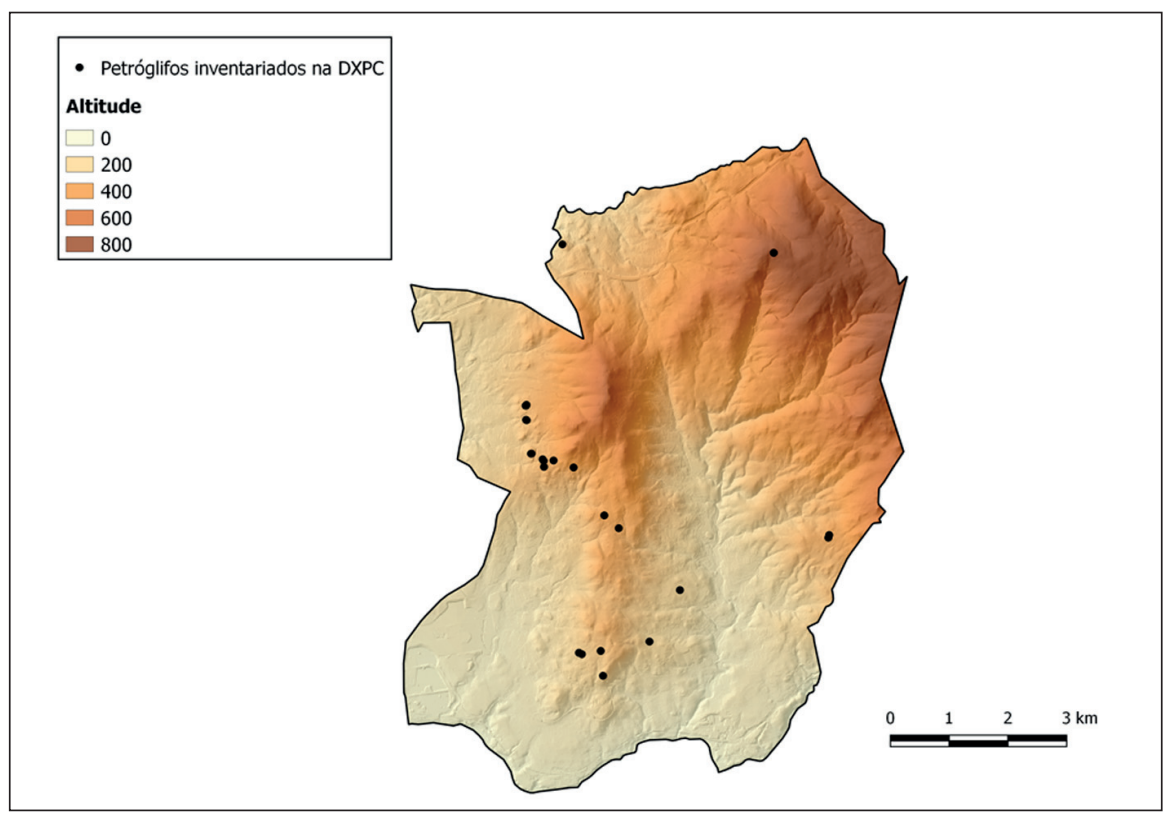

Figura 3. Distribución das estacións de arte rupestre despois das prospeccións.

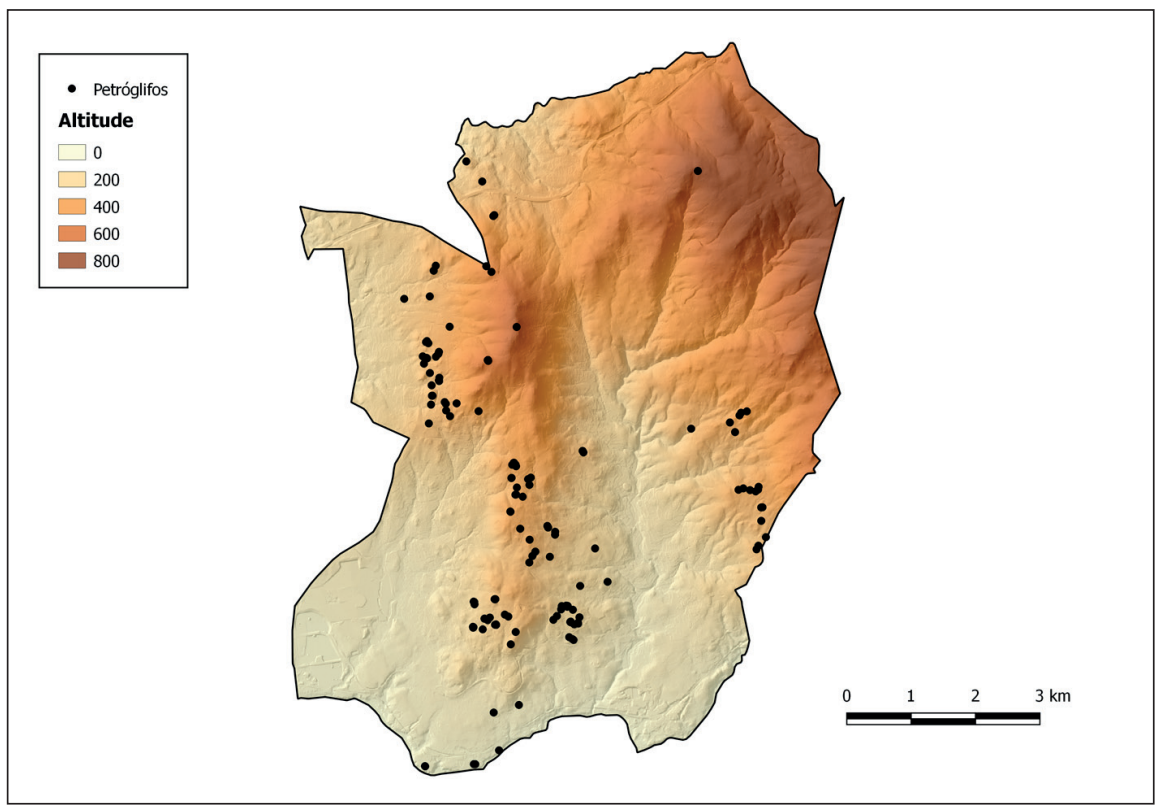

\section{A Distribución espacial}

A diversidade da arte rupestre pode estudarse, no que se refire a súa implantación no territorio, atendendo a diferentes criterios. As principais variables analizadas historicamente nos traballos sobre arte rupestre galaico, son as que algúns autores denominaron como características de primeira orde (RODRÍGUEZ-RELLÁN \& FÁBREGAS 2015), e que pretenden explicar a maior ou menor intensidade do fenómeno artístico en diferen- 
tes territorios. Estas análises adoitan centrarse en aspectos como a altitude e a proximidade aos recursos ou ás principais vías de tránsito (BRADLEY 1997; RODRÍGUEZ, GORGOSO \& FÁBREGAS 2008). Emporiso, nas últimas décadas e grazas ao desenvolvemento dos Sistemas de Información Xeográfica (SIX), o número de variables para analizar a relación das estacións gravadas e a paisaxe aumentou considerablemente (análises de visibilidade, pendente, xeoloxía...).

Así e todo, compre sinalar que este tipo de análises deixan fóra outras variables, non medibles ou cuantificables, pero que deberon de ter un peso importante para a ocupación do espazo polas sociedades autoras dos gravados. Este tipo de variables non matemáticas e máis interpretativas pretenden ser explicadas por algúns autores a través de perspectivas fenomenolóxicas (TILLEY1994; INGOLD 2000), que tentan descifrar aqueles aspectos sociais e simbólicos que só podemos descubrir a partir da experiencia. Por outra parte, nos últimos anos xurdiron tamén novos traballos que conseguiron, en certa medida, mesturar os SIX coa arqueoloxía fenomenolóxica, axudando a mellorar a interpretación das diferentes paisaxes (LLOBERA 1996; RODRÍGUEZ-RELLÁN \& FÁBREGAS 2015).

Aínda que non é o obxectivo deste traballo, imos tratar de aproximarnos aquí, de xeito breve, sobre algunhas destas variables, como a altitude á que se atopan as diferentes estacións rupestres, o tipo de soporte, ou a cronoloxía do gravado (prehistórico ou histórico).

No que se refire á altitude, os gravados rupestres da nosa área de estudo, ao igual que sucede no resto de Galicia (RODRÍGUEZ-RELLÁN et al. 2018), amosan unha tendencia a afastarse dos lugares máis elevados do entorno, preferindo -como xa se ten sinalado en moitas ocasións - as alturas intermedias (BRADLEY 1997). Fóra destas xeneralidades, existen variacións entre diferentes rexións na zona galega no que se refire a concentración de gravados a determinadas altitudes. Para a nosa zona, Rodriguez Rellán et al. (2018) sinala que, dentro do cluster Condado no que se enmarca o concello das Neves, a maioría das estacións rupestres (arredor do 63\%) sitúase entre os 350 e 500 metros. Analizando só a zona das Neves, e cos novos datos obtidos, puidemos observar unha distribución das superficies con gravados nun rango de altitude máis amplo. Aínda así, o número das estacións rupestres é maior arredor dos 350 metros que noutras altitudes, en conxunto, a maioría dos petróglifos concéntrase entre os 150 e 400 metros, mostrando semellanzas na ocupación do espazo con outras áreas como Carnota-Muros ou o Baixo Miño-Vigo (RODRÍGUEZ-RELLÁN et al., 2018).

Grazas as novas prospeccións, cada vez son máis os gravados prehistóricos de diferentes composicións temáticas, que se saen dos patróns de emprazamento clásicos, situándose nas cotas máis altas ou en zonas próximas ó litoral. Este tipo de emprazamento dos petróglifos, aínda sendo pouco frecuentes no noroeste peninsular, son moi significativos pois revelan que esta forma de transformar a paisaxe é máis ampla do que inicialmente se cría. Exemplos, deste infrecuente emprazamento témolo na nosa área de estudo, con gravados que se sitúan en cotas de 24 metros e moi próximas ao río Miño, ou arredor das zonas máis altas do territorio (787 metros). Por outra parte, este tipo de distribucións anómalas tamén se localizan noutras zonas do sur de Galicia e norte de Portugal próximas a nosa área de estudo. Algúns exemplos de superficies emprazadas a 
pouca altitude e situadas próximas ao litoral, témolo nos petróglifos de arte abstracto da Laxe do Lapón (O Rosal), ou de zoomorfos nas Carneiras (Tui), Montedor e Carrasqueira (Viana do Castelo) (PEREIRA 2017).

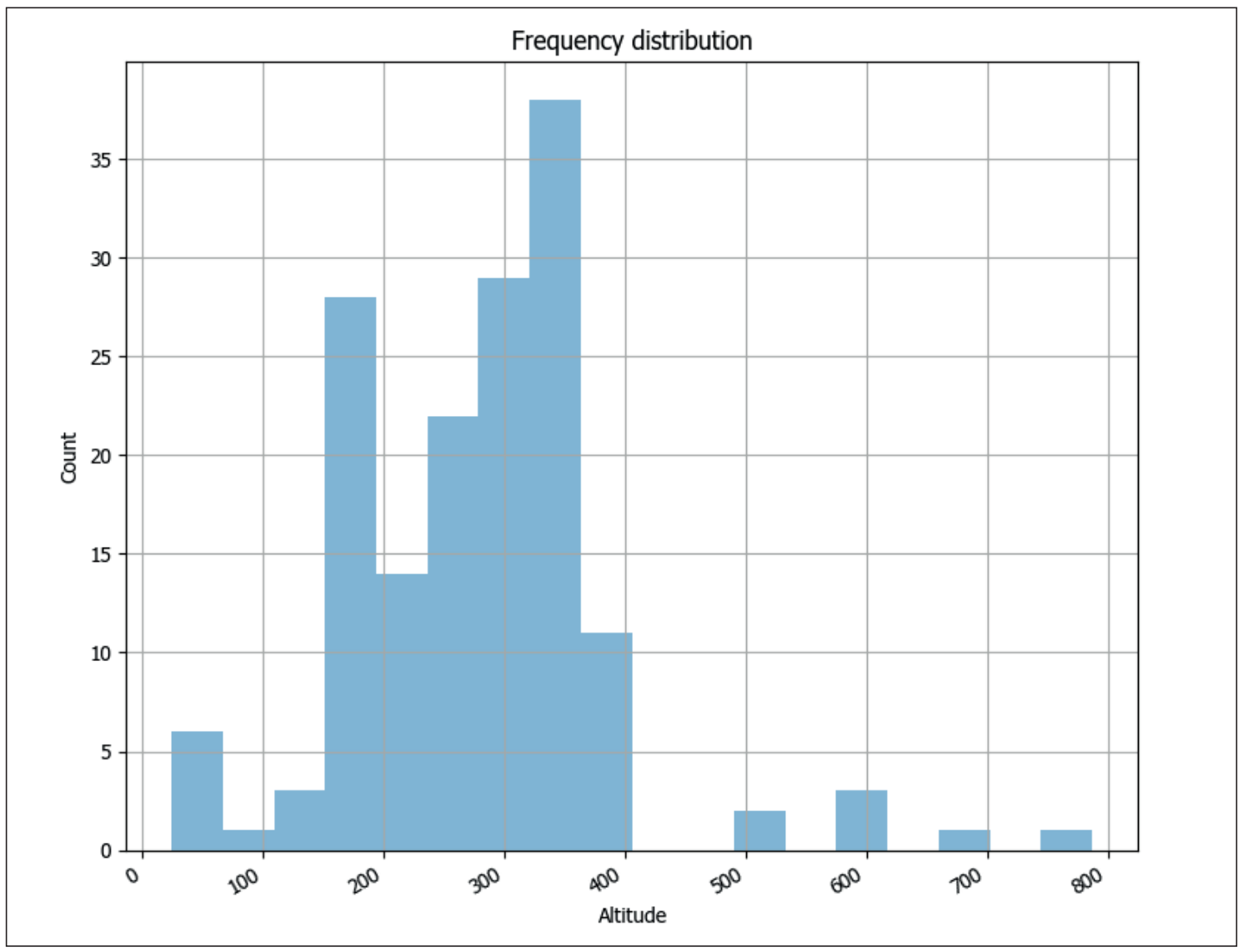

Figura 4. Distribución en cifras absolutas das estacións rupestres segundo a altitude.

Deste xeito, parece que a proximidade ao litoral e a altitude só funcionan como criterios condicionantes a nivel cuantitativo na distribución da arte rupestre, pero non a nivel cualitativo, pois é posible atopar case calquera tipo de representación da arte atlántica nestas zonas.

Atendendo ó número estacións rupestres, así como a súa proximidade, puidemos observar que, ao longo do territorio estudado aquí, a maioría dos petróglifos forman conxuntos. Este fenómeno de agrupacións de superficies con gravados sucédense ao longo do territorio e faise menos evidente nos grupos situados máis próximos ao litoral, que non tenden a situarse tan próximos.

Mediante a creación de diferentes áreas arredor dos petróglifos (Buffers de 50,100,200 e 300 metros), puidemos establecer unha serie de superficies de influencia para cada gravado que confirmaron a existencia de varios espazos de concentración. Temos que destacar que ó traballar sobre nunha zona limitada administrativamente como é un concello, e tendo en conta o número de superficies con gravados, decidimos valorar os datos só nesta escala local. Así, consideramos como grupos ou áreas de concentración, aqueles conxuntos que dentro dos diversos buffers establecidos, conten con 5 ou máis estacións de arte rupestre. 


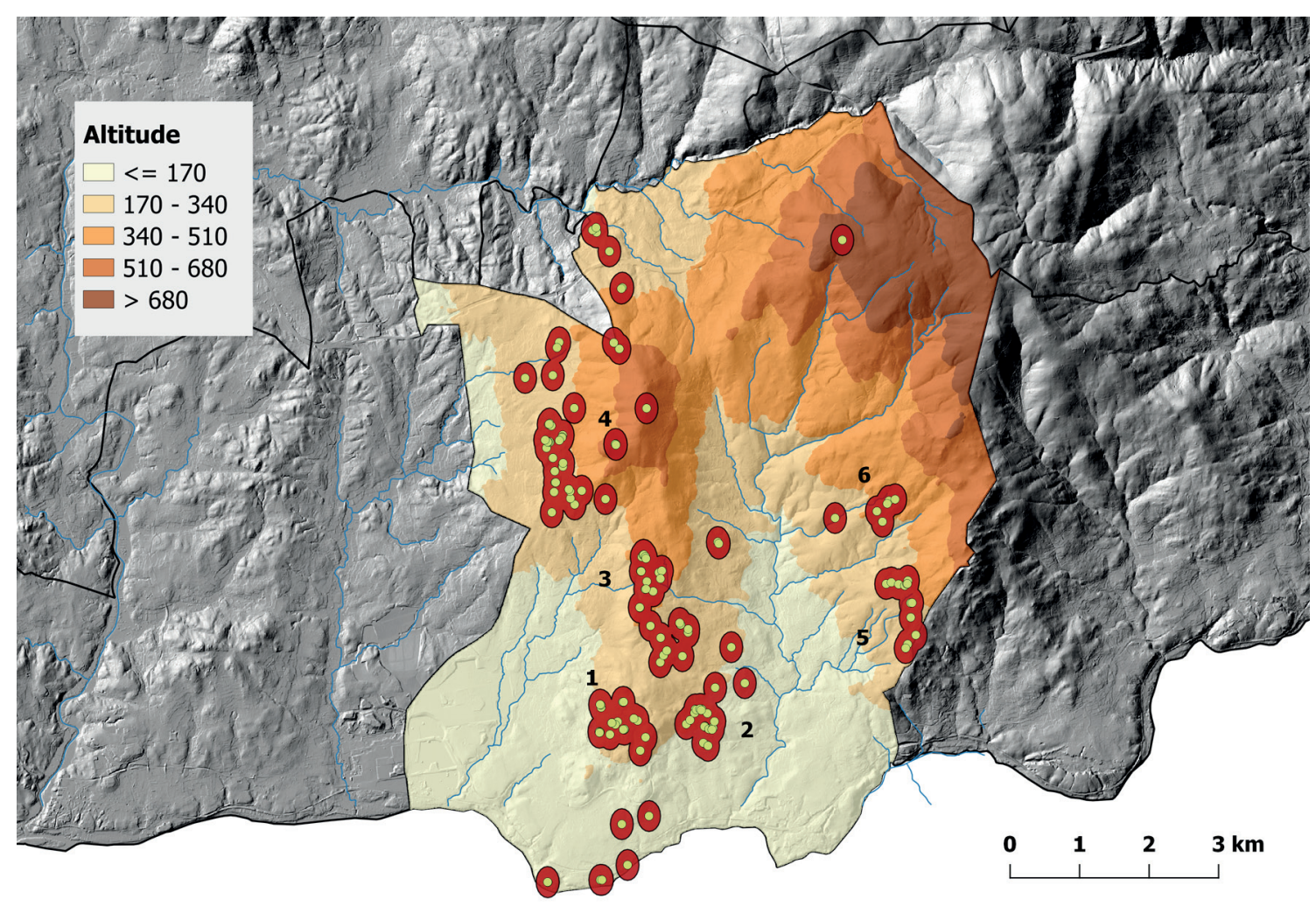

Figura 5. Agrupacións de arte rupestre mediante buffer de 200 m. Numéranse aquelas que ademais contan con 5 ou máis estacións

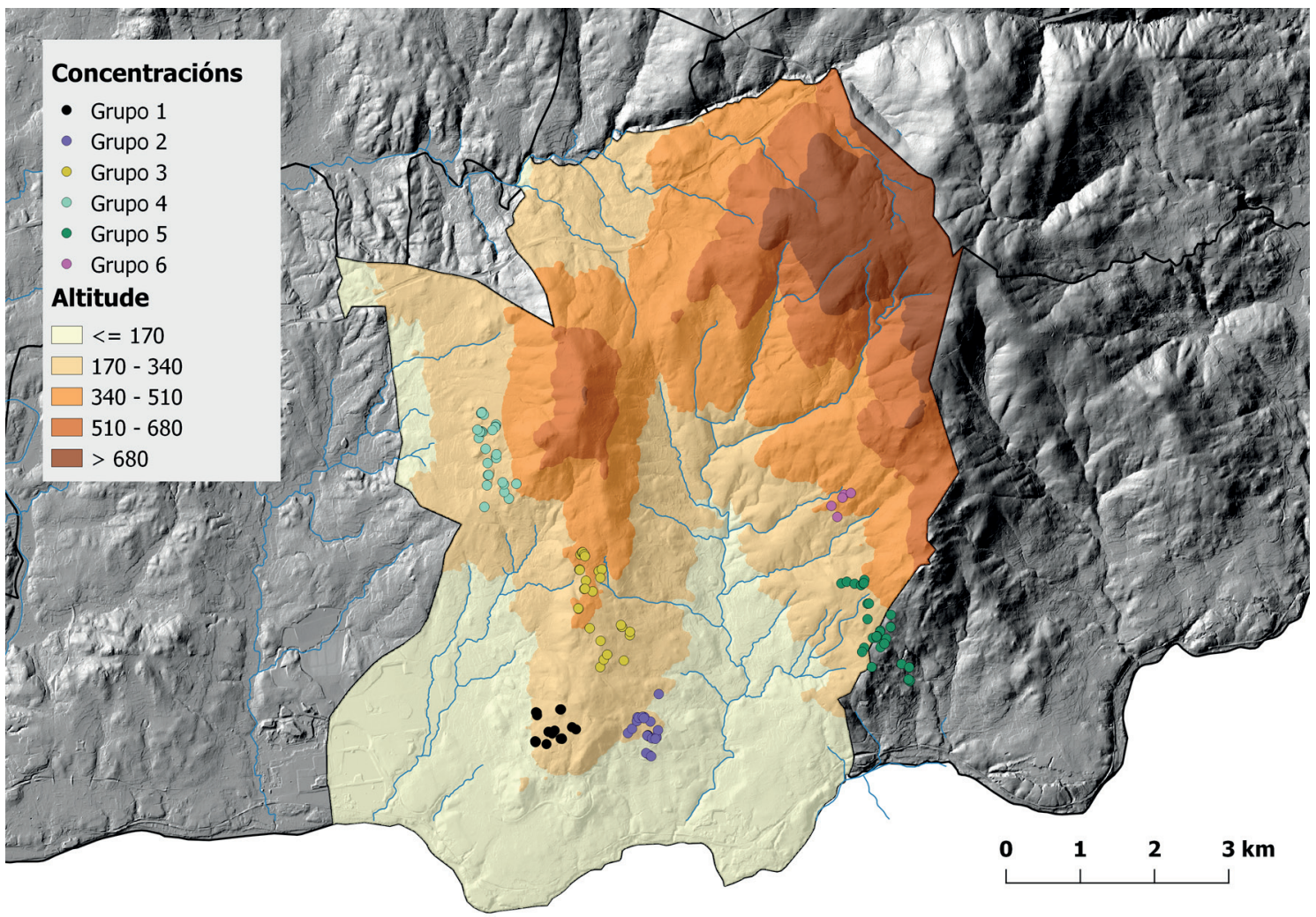

Figura 6. Grupos de estacións de arte rupestre. Tivéronse en conta tamén outras estacións (Grupo 5) que conforman o clúster xa fóra da área de estudo. 
Deste xeito, identificamos -segundo os criterios xa citados- 6 conxuntos ou agrupacións de estacións de arte rupestre no concello das Neves. O grupo 1 está composto por 10 estacións de arte rupestre; o segundo grupo por 15, o grupo 3 por 22 estacións, o cuarto grupo conta con 20 superficies; o quinto grupo ten 29 superficies e por último, o grupo 6 con tan só 6 superficies. Dentro destas agrupacións, existen diferentes números de rochas por cada estación como xa sinalamos, destacando os grupos que contan con 25 rochas gravadas (Grupo 1), ata os que teñen 41 superficies con petróglifos.

A través desta clasificación, observamos que as principais agrupacións ou conxuntos de gravados prehistóricos na zona de traballo encádranse entre os 170 e 340 metros de altitude. Fóra destas altitudes non conforman conxuntos, a excepción de parte do Grupo 3 e do Grupo 6 pero sempre en altitudes inferiores aos 400 metros. No caso do Grupo 5 observamos como o clúster continúa fóra das fronteiras administrativas do concello, polo que pareceunos importante engadir as restantes superficies que conforman a agrupación.

Por outra parte, das restantes estacións rupestres que non conforman agrupacións, máis da metade $(53,8 \%)$ se sitúan na mesma franxa que os principais núcleos sinalados, é dicir entre os 170 e os 400 metros. En canto ás superficies situadas en cotas superiores aos 400 metros, tan só foron detectadas 5 estacións de arte rupestre a estas altitudes, das que só dúas, se sitúan e posicións superiores aos 600 metros.

Por último, fóra dos principais núcleos temos 7 superficies situadas nas cotas máis baixas, por debaixo dos 150 metros, das que 6 se atopan emprazadas en posicións inferiores aos 80 metros. Ademais, tódalas superficies desta última clasificación localízanse o sur da nosa área de estudo, en lugares orientados cara ó río Miño.

Considerando o anterior, podemos ver como as sociedades autoras dos gravados seguen -de xeito xeral- unha serie de criterios ou normas para ocupar/transformar o territorio a través da arte rupestre. Na nosa área, ao igual que sucede noutras zonas do noroeste peninsular (ALVES2013), os petróglifos tenden a formar concentracións e, como xa sinalamos, a altitude supón un factor determinante na formación das mesmas.

Estas agrupacións sitúanse de xeito habitual en zona chás ou sen moita pendente (RODRÍGUEZ-RELLÁN \& FÁBREGAS 2015), feito que fixo relacionar historicamente os petróglifos co control de terminados lugares con recursos e que serían moi importantes para as sociedades prehistóricas (PEÑA \& REY 2001; FREDELL, KRISTIANSEN \& CRIADO 2010; CRIADO, FÁBREGAS \& SANTOS 2001; BRADLEY 1997). No caso que nos ocupa, é ben significativo que os principais grupos de estacións rupestres se sitúen sistematicamente en zonas chás (Chan de Teceláns, Chan da Mina, Chan de Grifos...) e tamén a maioría dos restantes petróglifos que non conforman agrupacións, a excepción dos que se localizan en asentamentos da Idade do Ferro como o Castro da Cividade ou o Castro de Altamira.

Deste xeito, os principais núcleos de arte rupestre situaríanse nunhas áreas intermedias de fácil acceso dende as zonas máis baixas ás áreas máis altas. Atendendo ó emprazamento dos gravados na nosa área, parécenos axeitada a hipótese do control sobre certas áreas húmidas e cunha grande importancia económica, nun momento no que se experimentan mudanzas climáticas de considerable relevancia (FÁBREGAS, MARTÍ- 
NEZ-CORTIZAS, BLANCO \& CHESWORTH 2003). Aínda que non se deben desbotar outros factores que terían influído tamén -en maior ou menor grao- na distribución dos gravados no territorio, como a elección de lugares onde a erosión dos gravados fose menor, ou a relación con vías de tránsito (RODRÍGUEZ-RELLÁN \& FÁBREGAS 2015).

Outro criterio valorado nos últimos estudos de arte rupestre para ter en conta a súa distribución espacial é a xeoloxía. Mediante o estudo dos datos da DXPC, recentes investigacións mostraron que a maioría dos gravados localizados en Galicia foron realizados en granito (VÁZQUEZ 2015). Se ben é certo que os afloramentos graníticos son os predominantes en Galicia, semella que o xisto ou outro tipo de rochas son menos empregadas nas áreas nas que existe esta clase de litoloxía. Así e todo, algunhas novas investigacións evidencian a existencia dun bo número de gravados feitos noutros materiais diferentes ao granito (GONZÁLEZ 2011; FÁBREGAS \& RODRÍGUEZ-RELLÁN 2012), polo que é posible que o número de petróglifos realizados noutros materiais aumente nun futuro, modificando as porcentaxes que vimos manexando actualmente.

No concello das Neves, o granito é un material inseparábel da realidade da arte rupestre da zona, onde só se localizaron 3 superficies con gravados noutro material diferente (xisto). A escolla dunha superficie en lugar de outra para gravar puido estar non só relacionada co tipo de rocha, senón tamén coa textura da mesma. Deste xeito, a textura funcionaría como un criterio restritivo na elección de superficies onde gravar, pois non sería importante só ver o gravado senón tamén tocar a superficie na que se representa (BRADLEY 2009).

\section{A COMPOSICIÓN TEMÁtica}

Cremos que o conxunto de petróglifos nesta área da conca do Miño é o suficientemente representativo, como para amosar conclusións significativas se atendemos á súa composición temática. Para comprender mellor o fenómeno rupestre nesta zona do Miño, consideramos pertinente ter en conta as estacións rupestres de áreas próximas, como as que se atopan no concello deArbo.

Para realizar a clasificación dos motivos, tomamos como referencia as divisións clásicas para a arte rupestre de estilo atlántico (PEÑA \& REY 2001; COSTAS \& NOVOA 1993) xunto cos recentes aportes para a zona galega (RODRÍGUEZ et al. 2018) adaptadosás peculiaridades da nosa área. Deste xeito, decidimos dividir a composición temática dos gravados en catro bloques: Motivos xeométricos, motivos históricos, varios prehistóricos e gravados naturalistas. O criterio empregado para diferenciar entre gravados históricos e prehistóricos, foron o tipo de motivo representado (cruces, alfabetiformes...), así como as características dos mesmos (como a forma en $\mathrm{V}$ dos sucos ou a maior ou menor erosión dos gravados).

A análise das rochas evidenciou de xeito claro, como acontece noutras áreas do noroeste peninsular (FÁBREGAS \& RODRÍGUEZ 2012; ALVES \& REIS 2017; RODRÍGUEZ et al. 2018), un predominio dos motivos de arte abstracto-xeométrico no que destacan aquelas representacións máis sinxelas, como as coviñas. 


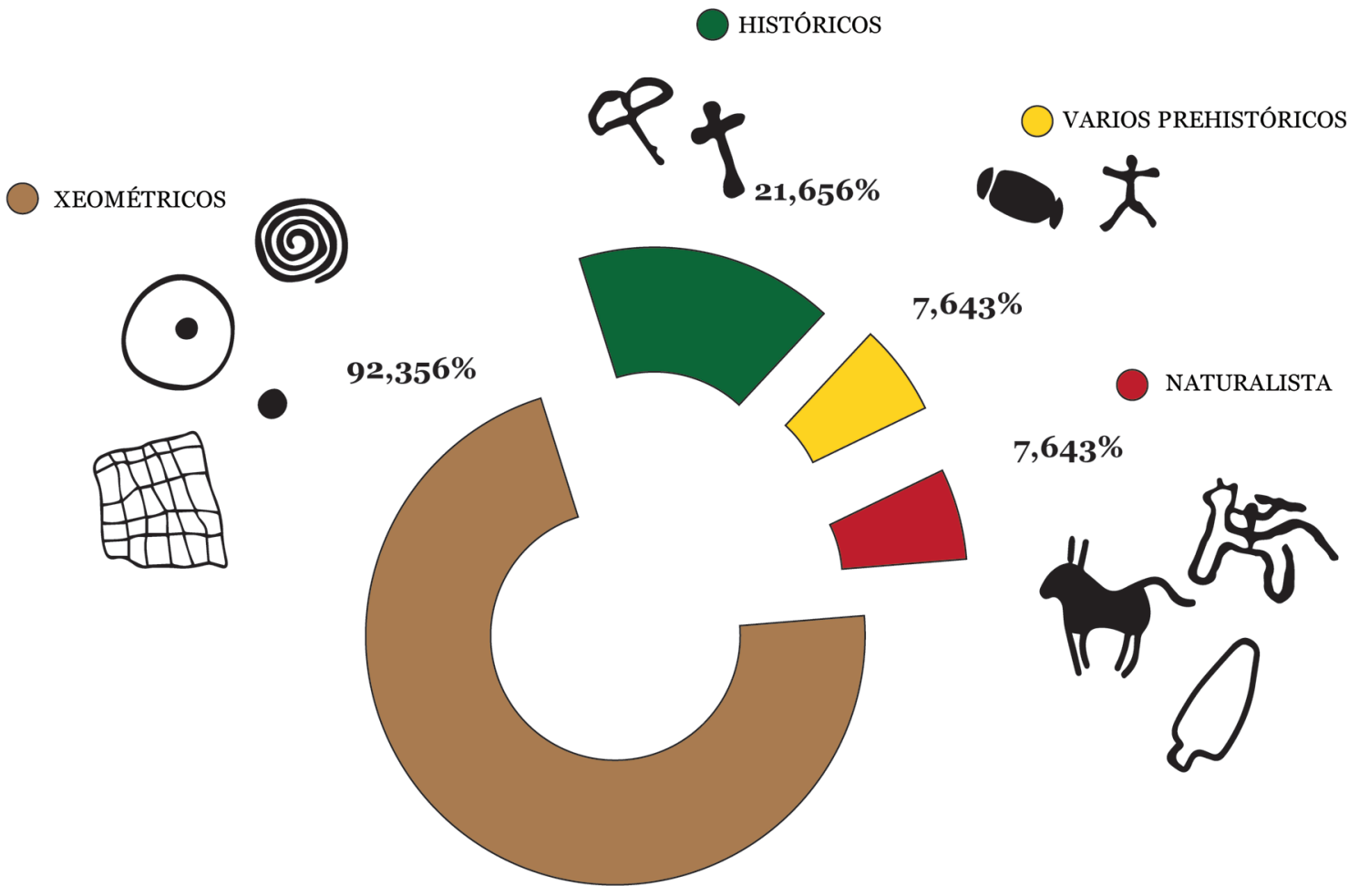

Figura 7. Ordenación por grupos e estacións rupestres.

Atendendo a esta primeira división, tamén destaca o aumento das figuras naturalistas, principalmente os zoomorfos, que representan un número considerable para situarse fóra dos núcleos principais onde se desenvolven este tipo de representacións. Ademais, antes das prospeccións só se coñecían un par de superficies con gravados de animais, e non había testemuños da presenza de armas nesta parte da bacía do Miño, polo que estes novos achados supoñen unha novidade para a arte rupestre do noroeste.

Por outra parte, o grupo de gravados históricos formado por alfabetiformes, cruces ou representacións de cronoloxía indeterminada, como as figuras tipo ballesta (SANTOS 2007) ou os xogos de alquerque (COSTAS \& NOVOA 1993) aparecen, por ser un grupo moi amplo e heteroxéneo, nun número considerablemente alto de estacións rupestres.

Por último, o bloque denominado "varios prehistóricos", conformase por gravados dos que se coñecen escasos exemplos no noroeste peninsular, tales como antropomorfos, idoliformes, barcos ou podomorfos, incluíndo ademais os muíños rupestres característicos do sur de Galicia e o norte de Portugal. Aínda que estes últimos son artefactos funcionais, decidimos incluílos dentro da categoría de gravados rupestres, como xa fixeran outros autores, pois a súa relación coa arte rupestre é innegable, así como a súa similitude a hora de ocupalo territorio.

A división dos motivos por estacións rupestres mostra, como xa indicamos, unha alta presenza das representacións máis sinxelas como as coviñas e os circos simples. Fóra destes destaca unha alta presenza -dentro deste grupo xeométrico - dos reticulados, que se atopan presentes en ata 30 estacións. Este tipo de figuras son moi comúns no sur de Galicia (COSTAS, MARTÍNEZ \& NOVOA 1999; VILAR \& MÉNDEZ 2009) e norte de 
Portugal (MARTINS 2006; ALVES \& REIS 2017) e aparecen en moitas ocasión asociadas a figuras de cuadrúpedes, aínda que na área de traballo é habitual que na maioría das ocasións estean illados ou asociados a outros motivos xeométricos.

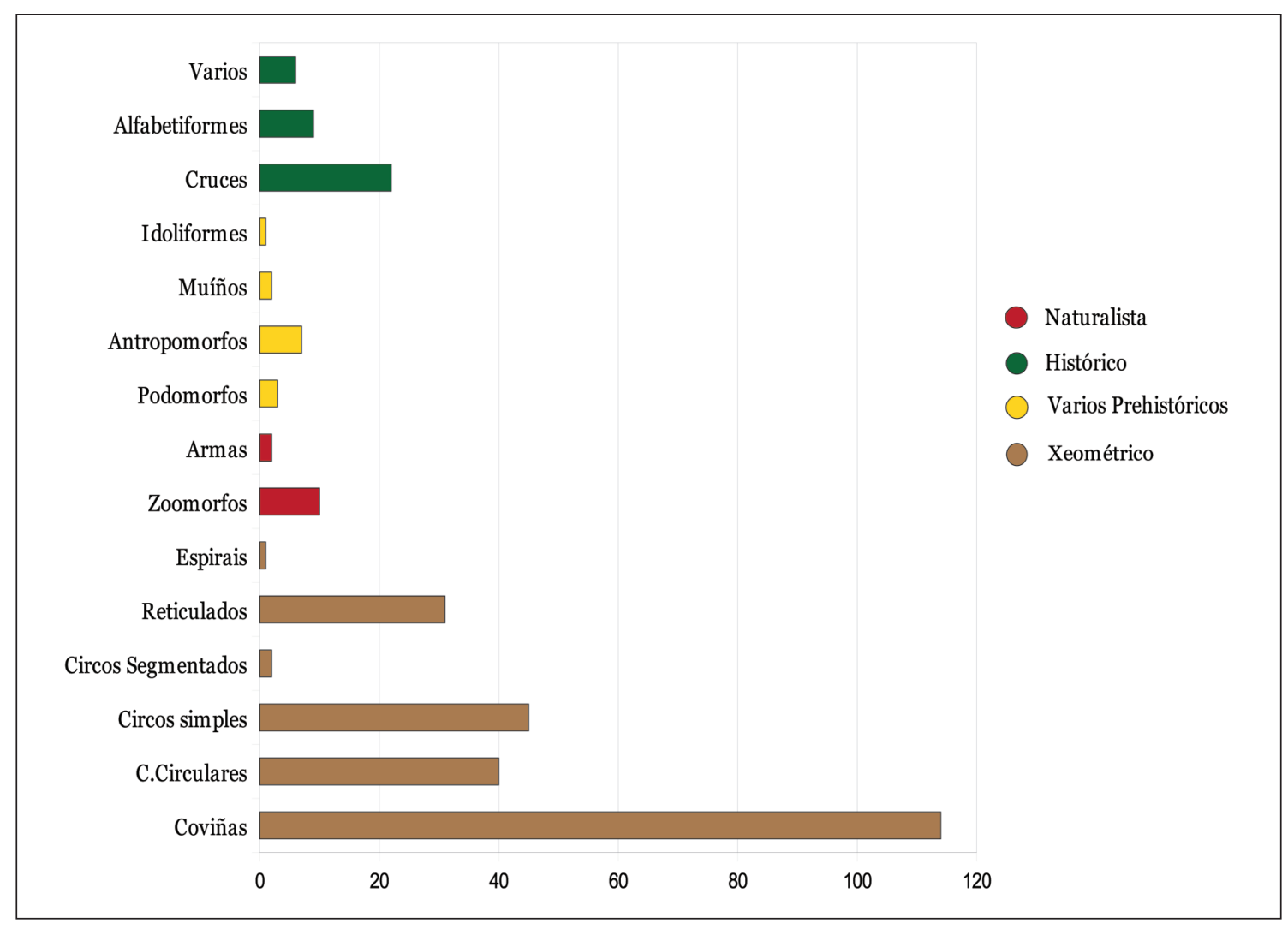

Figura 8. Ordenación dos motivos por estacións rupestres.

Tamén debemos sinalar que as representacións de reticulados ou figuras axadrezadas son moi diversas en canto a tamaños e formas, pudendo apreciar figuras de catro cuadrículas ata ás que conteñen máis de 70. Ademais, en moitas ocasións estas figuras -normalmente as de maior tamaño- aparecen incompletas.

A cronoloxía destes motivos é complexa, pois aínda que algunhas representacións son claramente prehistóricas (REY, FRANCO \& EIROA 2017), existen tamén exemplos de figuras similares en contextos máis modernos, e que foron interpretados nalgúns casos como taboleiros de xogo (COSTAS \& NOVOA 1993; FERNÁNDEZ 2017).

Outros motivos do grupo abstracto-xeométrico, como as espirais ou os circos segmentados, presentan números moi reducidos. O primeiro motivo só aparece nunha estación rupestre, e o segundo aínda sendo unha figura máis común na arte rupestre galega, presentase só en dúas superficies.

O grupo naturalista, pola súa parte, divídese en dúas categorías: zoomorfos e gravados de armas. Debemos sinalar, que cando falamos de zoomorfos, estamos a referirnos principalmente a gravados de cuadrúpedes, xa que son estes os únicos que aparecen representados de xeito claro. Estes petróglifos de animais son comúns na arte rupestre do noroeste, fundamentalmente nas zonas costeiras suroccidentais as súas inmediacións, e 
o norte de Portugal (VÁZQUEZ, RODRÍGUEZ \& FÁBREGAS 2018; ALVES 2013,2017, BETTENCOURT 2017). Os gravados de armas aparecen nun número moito máis reducido, representando só 1,7\% do corpus de arte rupestre en Galicia (RODRÍGUEZ -RELLÁN et al. 2018). Por esta razón, resultan interesantes os resultados obtidos nesta investigación, xa que foi posible localizar dúas estacións de arte rupestre con figuras de armas nesta zona da bacía do Miño. Con todo, a presenza de armas nesta zona non resulta de todo única, pois coñécese a presenza deste tipo de motivos na bacía do Miño (SILVA \& CUNHA 1986; ALVES \& REIS 2017; SANTOS \& BETTENCOURT 2017) e en áreas próximas (Petróglifo do Picoto) .

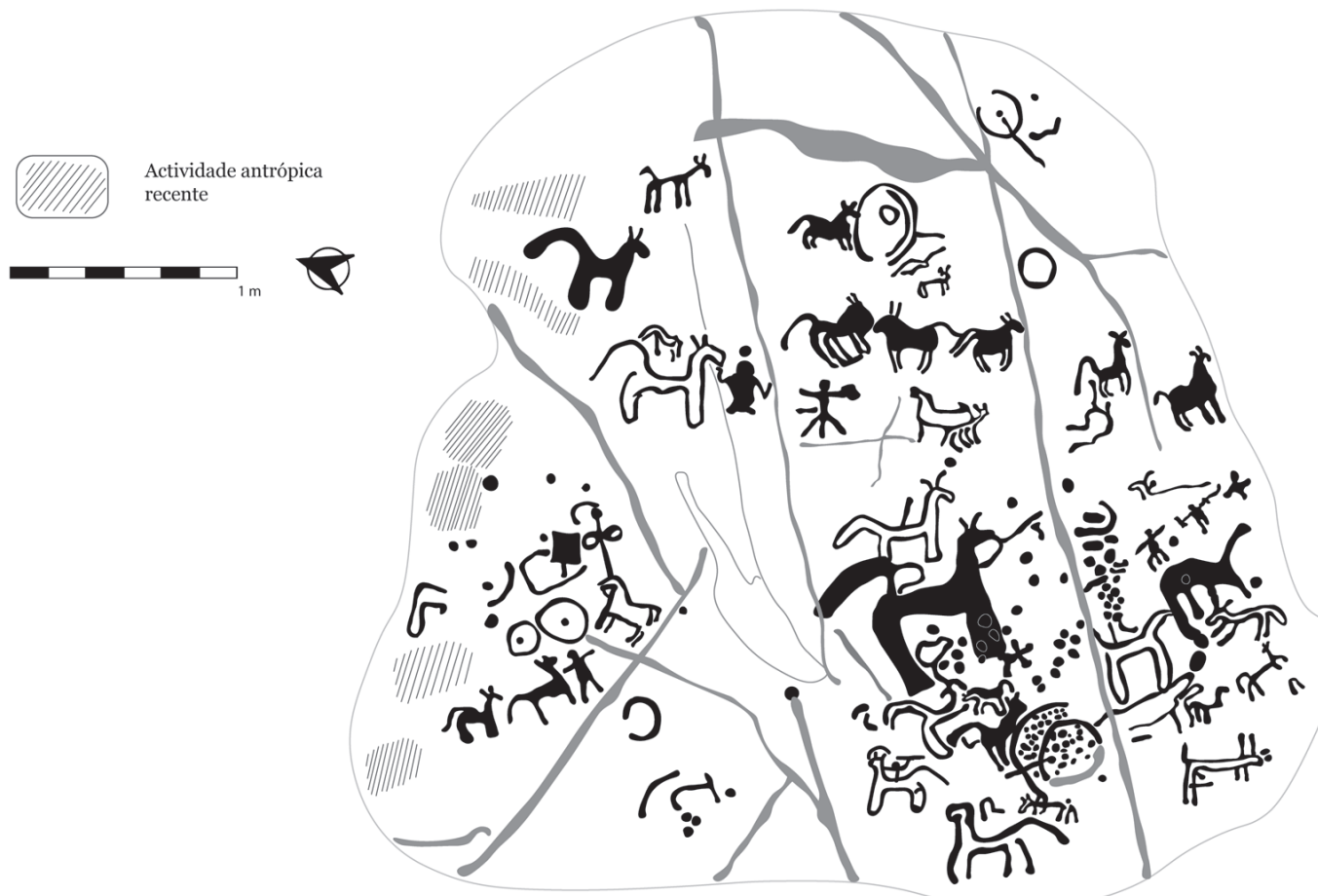

Figura 9. Calco de parte do petróglifo da Coutada p3.

Os cuadrúpedes pola súa parte, aparecen en 10 estacións de arte rupestre, pero presentan unha distribución dispar no número de figuras por panel. É posible atopar petróglifos cun só zoomorfo, e superficies que presentan máis de 20 figuras de animais.

No caso dos motivos de época histórica, a temática máis repetida son as figuras cruciformes, como ocorre noutras rexións do Baixo Miño litoral (VÁZQUEZ 2016). Dentro destes motivos, hai unha ampla gama de representacións (cruces latinas, gregas, potenzadas...) que ademais adoitan formar conxuntos de varias figuras na mesma rocha. Outros motivos históricos como os alfabetiformes ou as ferraduras e xogos de alquerque, encóntranse nunha porcentaxe considerablemente menor. 


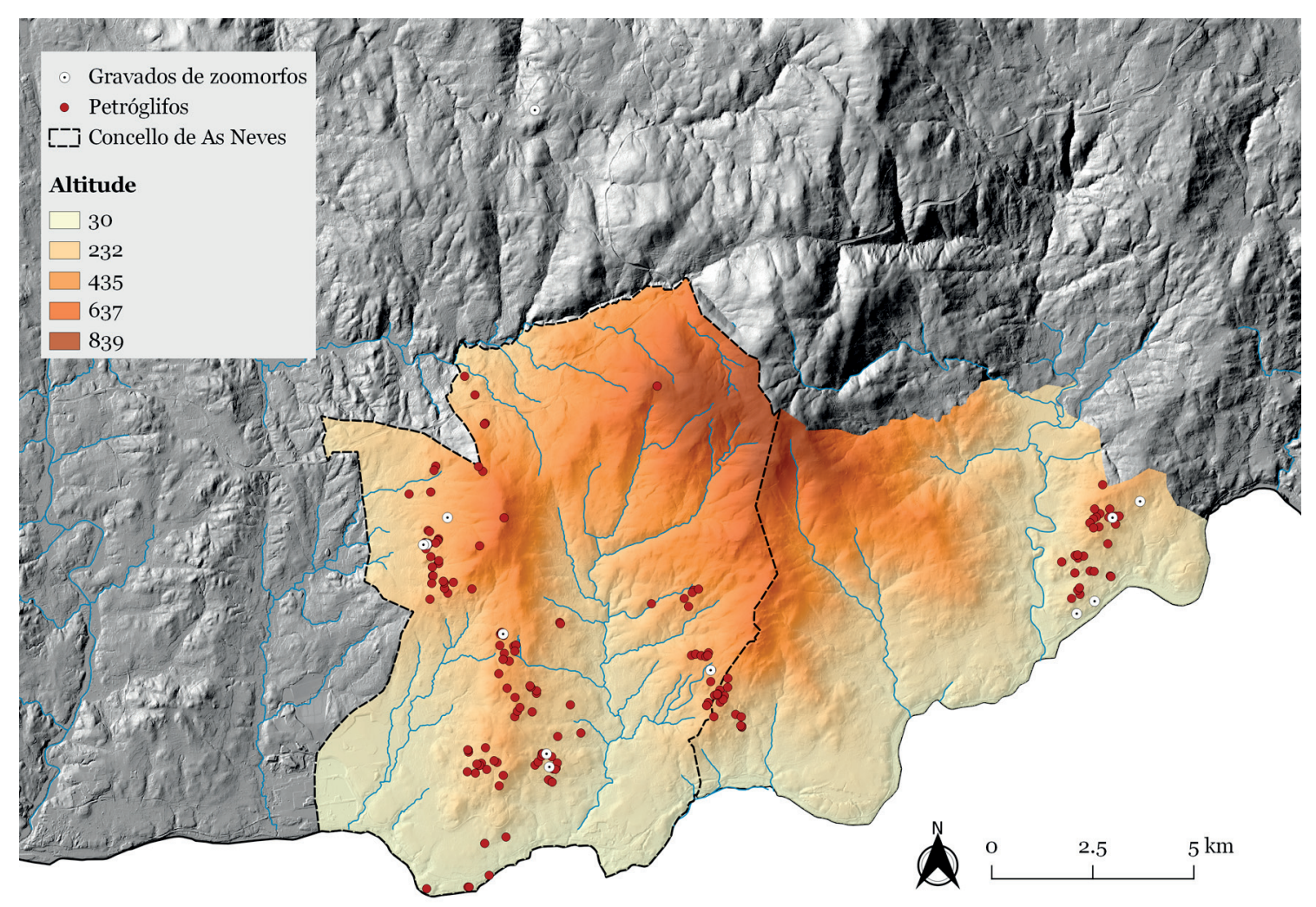

Figura 10. Mapa distribución de zoomorfos.

Por último, os motivos comprendidos no grupo denominado "varios prehistóricos", son en conxunto moi minoritarios, tanto na nosa área de estudo como no noroeste peninsular. Destaca a presenza dun posible idoliforme, así como a existencia de muíños rupestres nunha zona da bacía do Miño onde se descoñecían este tipo de figuras. Dentro deste grupo, a temática máis abundante son as figuras antropomorfas representadas de diferentes xeitos, e que mostran evidentes semellanzas coas doutras zonas da bacía do Miño e da área galega (COSTAS \& PEREIRA 1998; CERNADAS 2007). Estes motivos aparecen formando conxuntos, relacionados con zoomorfos en escenas de caza ou monta, e illadas xunto a temas xeométricos. Ademais, nalgunhas ocasión represéntanse portando armas, como escudos ou lanzas, algo que non é tan habitual. É de destacar o feito de que a maioría das figuras antropomorfas de estilo máis esquemático se atopen concentradas en só dúas superficies; mentres que os antropomorfos relacionados con cuadrúpedes ou que portan obxectos aparezan nun maior número de superficies.

\section{REXISTRO E INVENTARIO DOS GRAVADOS RUPESTRES}

Como resultado dos traballos realizados no concello das Neves no ano 2018 foron identificadas 119 estacións rupestres, que xunto coas 37 do concello de Arbo, elevan a un total de 156 o número de conxuntos de arte rupestre nesta área da bacía do Miño.Como xa vimos antes, a distribución dos gravados atendendo aos catro bloques temáticos é bastante desigual, presentando un dominio dos motivos de tipo xeométrico en ámbolos 
dous concellos. A desigualdade no número de estacións rupestres entre os concellos estámotivada, probablemente, pola falta de estudos específicos no concello de Arbo, polo que é posible que novas investigacións sobre esta zona amosen un maior número de superficies gravadas das coñecidas actualmente.

Ata agora analizamos os petróglifos atendendo ás agrupacións por estacións rupestres, porén, os resultados son máis significativos se vemos a distribución e número de motivos por superficie, e dicir, por número de rochas gravadas. Para as seguintes análises teremos en conta só as estacións de arte rupestre que foron obxecto de estudo neste traballo, e que pertencen na súa totalidade ao concello das Neves. Podemos dividir as 119 estacións rupestres identificadas neste concello nun total de 223 rochas gravadas.

\begin{tabular}{|c|c|c|}
\hline Grupo & Arbo & As Neves \\
\hline Xeométrico & 37 & 108 \\
\hline Naturalista & 4 & 8 \\
\hline V. Prehistóricos & 1 & 11 \\
\hline Históricos & 1 & 31 \\
\hline
\end{tabular}

Figura 11. Estacións rupestres nos concellos de As Neves e Arbo.

As análises realizadas evidencian unha clara tendencia á distribución dos motivos xeométricos en varias rochas dentro dunha mesma estación rupestre, algo que non é tan habitual con outros motivos, que tenden á concentrarse nunha mesma superficie. Os motivos xeométricos que presentan unha maior distribución por rochas son as coviñas, seguidas polos circos simples. Con todo, un dos motivos máis habituais e que aparece en 42 superficies son as figuras reticuladas, que dotan a esta zona e á área da bacía do Miño dunha entidade propia. Fóra deste territorio non se atopan este tipo de motivos nestas proporcións tan elevadas. No grupo xeométrico, é relevante o feito de que representacións de maior complexidade como as combinacións circulares tendan a unha menor dispersión que os circos simples, a pesar de atoparse case no mesmo número de estacións rupestres. Pola súa parte, os motivos naturalistas aínda que aparecen nun menor número, non adoitan ter unha grande dispersión por rochas gravadas, senón que o máis habitual é ver unha concentración destes motivos en superficies próximas. Algo semellante acontece cos gravados de cruces dentro do grupo histórico, onde os cruciformes aparecen na maioría dos casos en grande número, pero nunha soa superficie.

As análises de correlación realizadas sobre as 223 rochas identificadas mostraronunha disociación entre case tódolos motivos históricos e prehistóricos, fundamentalmente entres os grupos de alfabetiformes e de varios prehistóricos. Nos casos nos que se establece unha correlación entre ámbolos dous grupos, as figuras históricas adoitan estar asociadas ás representacións máis simples, como as coviñas ou os circos simples. Como excepción a esta norma termos os motivos cruciformes nos que se aprecia unha dispersión maior e que se presentan en superficies con zoomorfos, reticulados ou antropomorfos. Por outra parte, o grupo de petróglifos históricos gardan unha forte relación entre eles, sendo habitual observar superficies nos que as figuras comparten a mesma laxe, especialmente no caso das cruces e os alfabetiformes. 


\begin{tabular}{|ccc|}
\hline Motivos & $N^{0}$ de rochas nas que estan presentes & \% respecto ao total de superficies \\
\hline Coviñas & 155 & $69,50 \%$ \\
\hline C.Circulares & 22 & $9,86 \%$ \\
\hline Circos simples & 58 & $26,00 \%$ \\
\hline Circos Segmentados & 3 & $1,34 \%$ \\
\hline Reticulados & 42 & $18,83 \%$ \\
\hline Espirais & 1 & $0,44 \%$ \\
\hline Zoomorfos & 8 & 3,58 \\
\hline Armas & 3 & $1,34 \%$ \\
\hline Podomorfos & 2 & $0,89 \%$ \\
\hline Antropomorfos & 7 & $3,13 \%$ \\
\hline Muíños & 2 & $0,89 \%$ \\
\hline Idoliformes & 1 & $0,44 \%$ \\
\hline Cruces & 21 & $9,41 \%$ \\
\hline Alfabetiformes & 13 & $5,82 \%$ \\
\hline Varios & 4 & $1,79 \%$ \\
\hline
\end{tabular}

Figura 12. Número e porcentaxe de rochas nas que se documentaron este tipo de motivos.

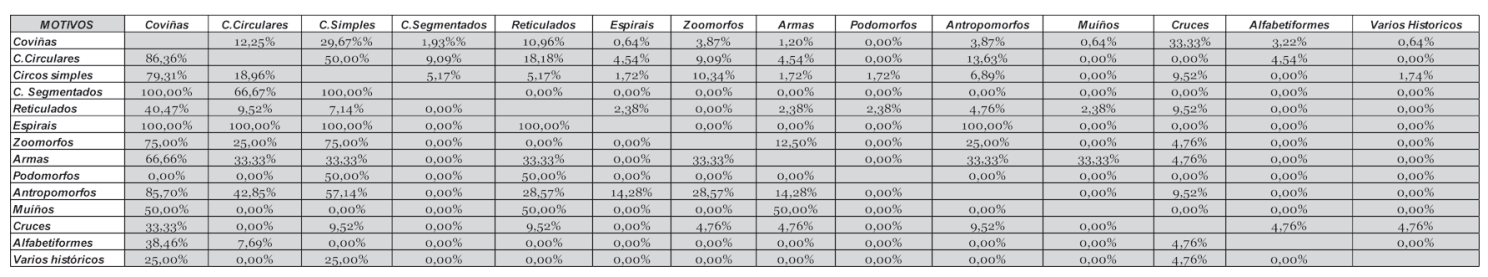

Figura 13. Porcentaxe de correlación dos motivos segundo a totalidade das superficie.

No que respecta aos motivos prehistóricos, o grupo xeométrico presenta unha grande relación entre os seus motivos, primordialmente entre os circos simples, as combinacións circulares e as coviñas. Outros motivos xeométricos, como as figuras reticuladas e as espirais, tamén están interrelacionadas cos motivos deste grupo, aínda que en menor medida.

As figuras naturalistas, por desgraza, preséntanse en poucas superficies, o que dificulta a súa análise. Porén, dentro do seu reducido número, observamos como os zoomorfos mostran unha tendencia á asociación coas combinacións de círculos, os circos simples, as coviñas e as figuras antropomorfas. Pola súa parte, o exiguo número de motivos de armas aparece relacionado fundamentalmente co grupo xeométrico.

Por último, as análises realizadas evidencian que as únicas superficies que presentan un único motivo son as que teñen como temática coviñas, figuras reticuladas e alfabetiformes, mentres que as demais figuras aparecen sempre asociadas a outros gravados.

\section{Conclusión}

O estudo sistemático da arte rupestre no concello das Neves, levou a aumentar considerablemente o número de rochas gravadas, a vez que evidenciou a necesidade de incre- 
mentalos traballos en zonas pouco estudadas como esta. Ademais, o emprego de novas técnicas de rexistro, coma nomeadamente a fotogrametría, contribuíu de forma exponencial ao devandito aumento dos motivos gravados. É posible que a restrición das investigacións ás zonas clásicas da arte rupestre, así como a límites administrativos actuais non faciliten o coñecemento integral do fenómeno da arte rupestre na súa totalidade.

Os novos achados expostos neste traballo, veñen a confirmar o sinalado nos últimos anos por diversos autores, corroborando a existencia de novas superficies con gravados rupestres en zonas historicamente pouco estudadas como o norte de Portugal (RODRÍGUEZ \& FÁBREGAS 2013; ALVES 2013,2017; ALVES \& REIS 2017; BETTENCOURT 2017; COSTAS \& HIDALGO 2005), Lugo (GONZÁLEZ 2011,2019), Ourense (COMENDADOR \& GONZÁLEZ2017) ou León (ENCINAS, RODRÍGUEZ \& PRIETO 2008; CAMPOS 2018). Deste xeito, o incremento no número de petróglifos, así como o descubrimento de superficies con temática de arte atlántica en lugares onde se pensaba que era inexistente, obrigan a reflexionar sobre unha posible continuidade e ampliación deste fenómeno en zonas que ata hai ben pouco tan só posuían un exiguo número de superficies gravadas.

Así e de cara o futuro, parece imprescindible continuar traballando fóra das zonas tradicionais de distribución dos petróglifos, facilitando a creación dun novo corpus de arte rupestre, limitado polas divisións administrativas do noroeste peninsular.

\section{Agradecementos}

A Ester Álvarez, Miguel de Taboexa, Cándido Verde, Eduardo Méndez Quintas e José Alonso que axudaron na prospección da zona. 
Figura 14. Petróglifo das Bouzas 2, onde se aprecia a presenza dunha figura antropomorfa con escudo que pasara inadvertida en traballos anteriores.

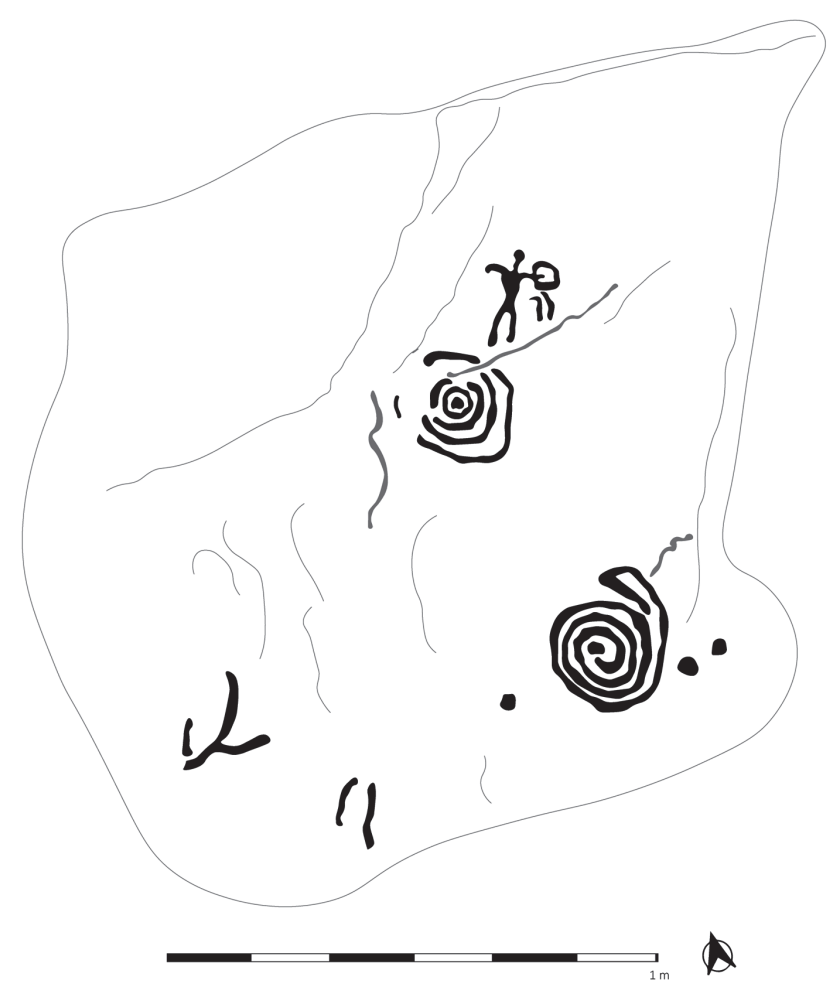

Figura 15. Calco do petróglifo daChan de Teceláns 1.
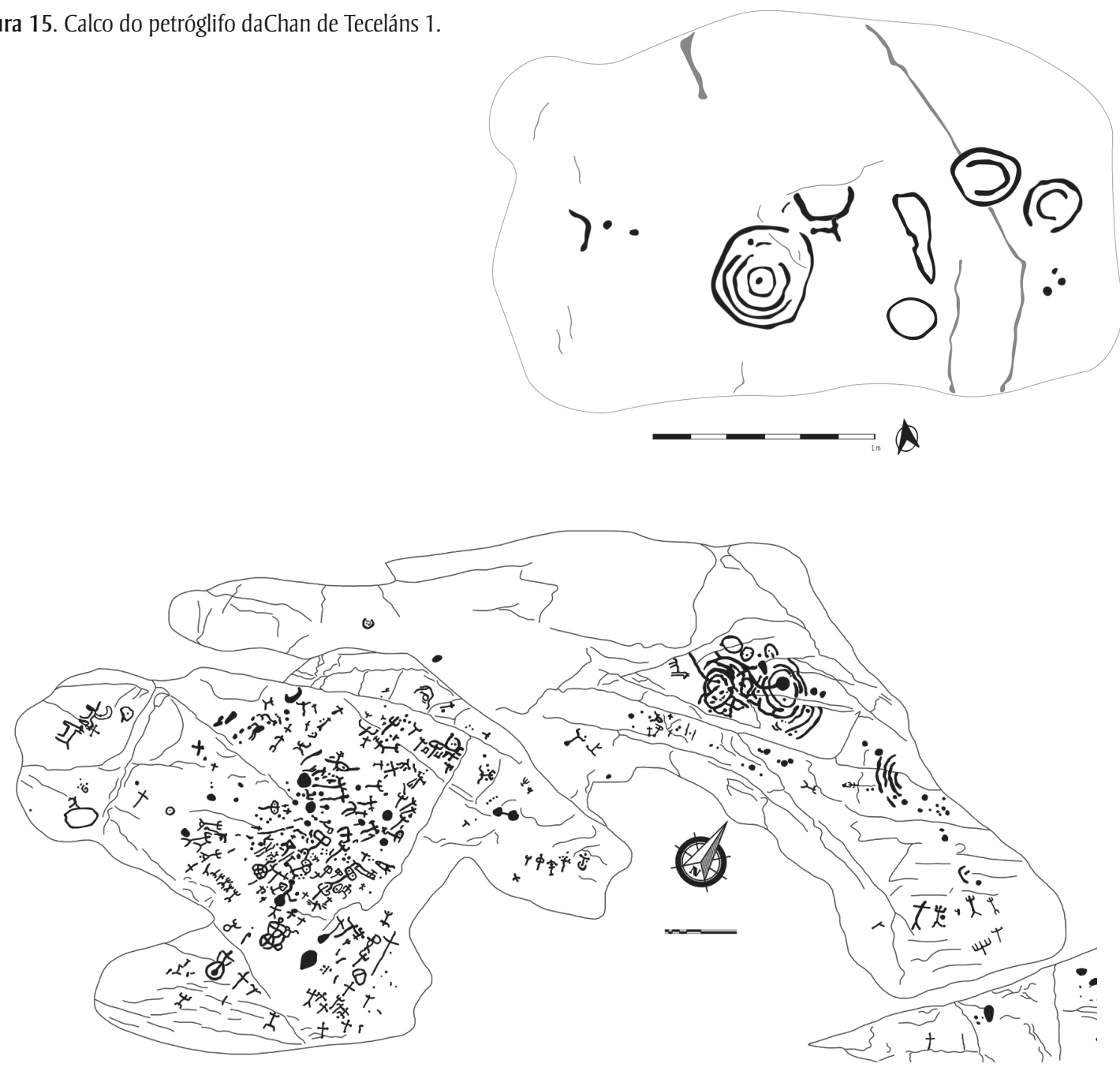

Figura 16. Calco do petróglifo da Coutada p1 (deseño de Eloy Martínez Soto en MÉNDEZ 2018). 
$-2-{ }_{1 \mathrm{~m}} \mathbb{Q}$

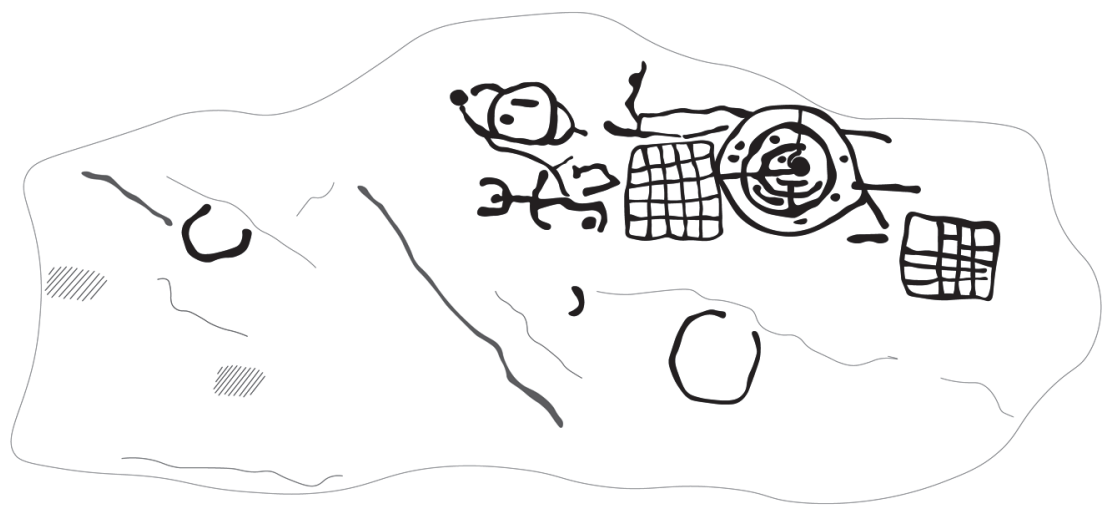

Figura 17. Calco do petróǵlifo dos Pociños 3.
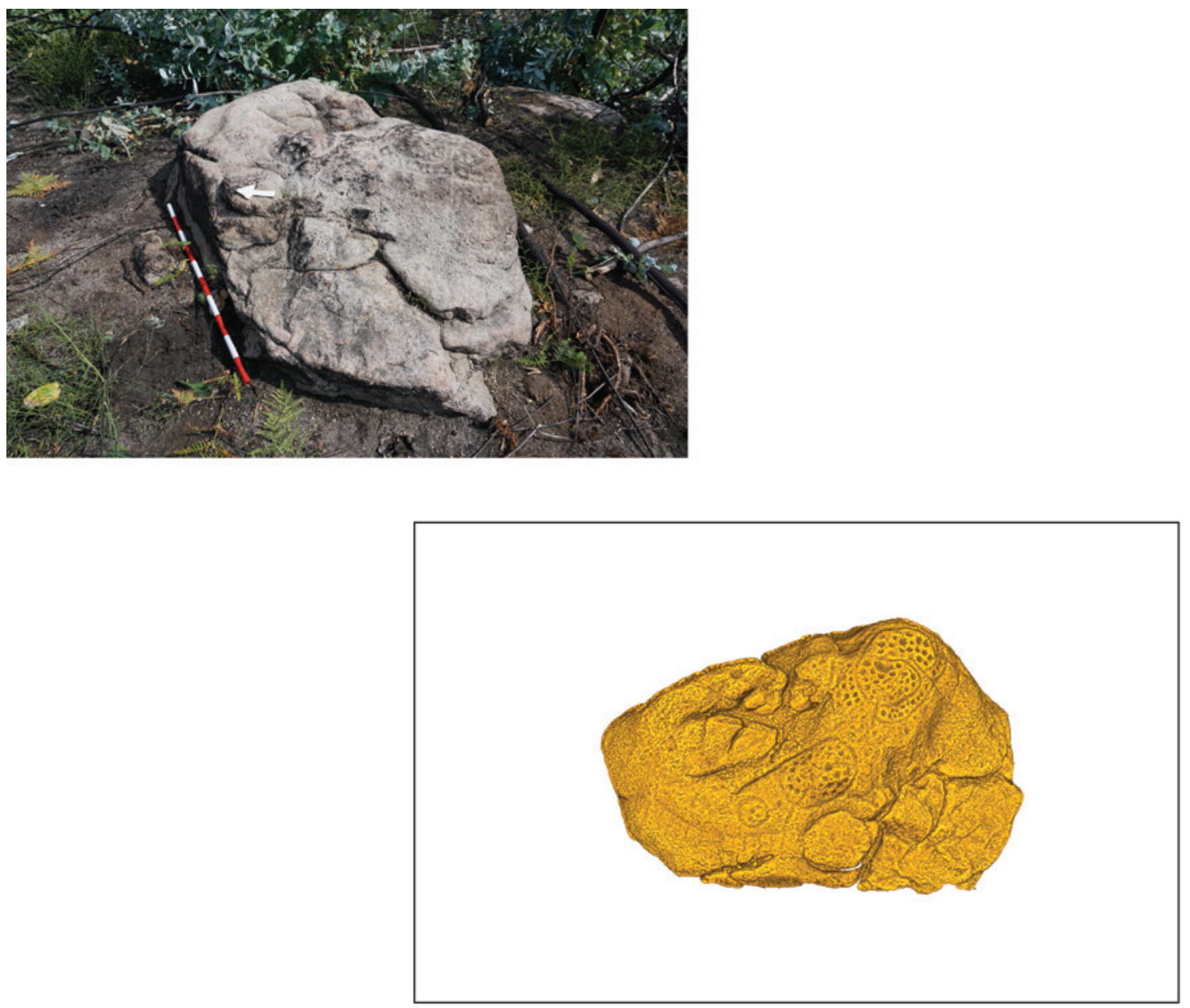

Figura 18. Fotografía e fotogrametría do petróglifo das Eiras. 
Cadro 1. Rexistro das superficies inventariadas.

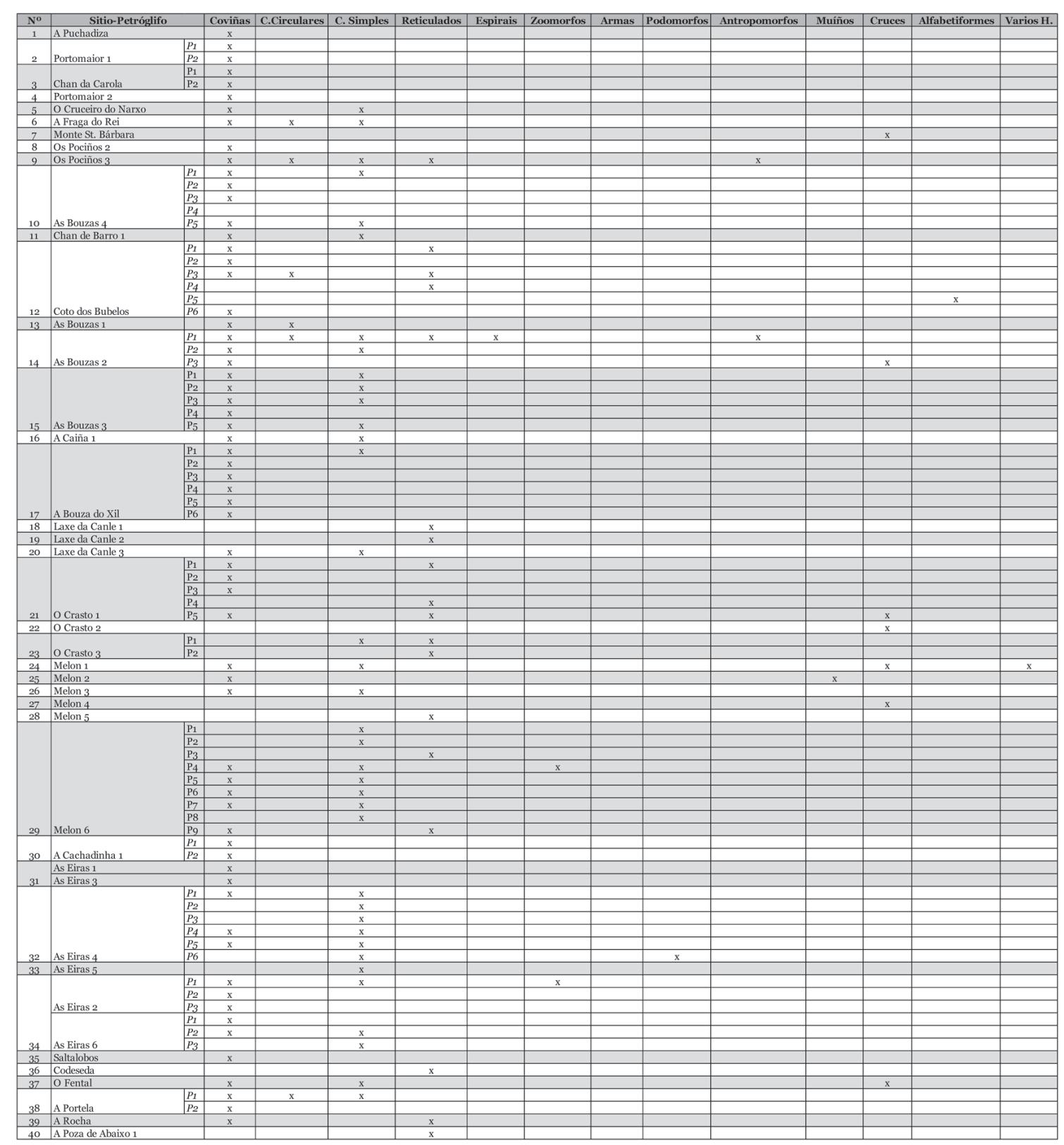


Cadro 2. Rexistro das superficies inventariadas.

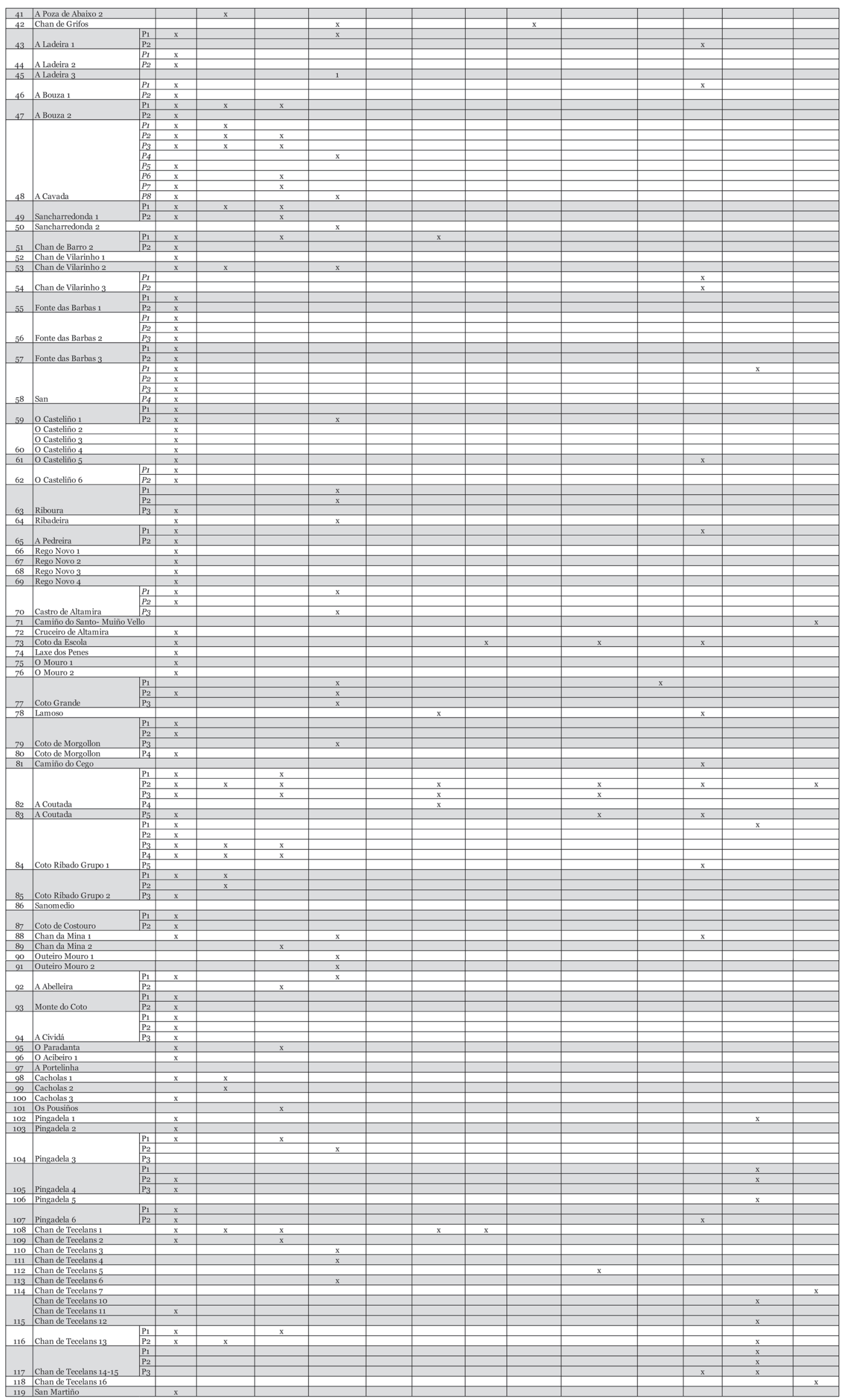




\section{Bibliografía}

AMADO REINO, X.; MARTÍNEZ LÓPEZ, M.; C.;CHAO ÁLVAREZ, F. J. 1998. La arqueología en la gasificación de Galicia 2: evaluación de impacto arqueológico en la red Vigo- Porriño. Trabajos en Arqueología del Paisaje (TAPA) 4, Santiago de Compostela.

ALVES, L. BACELAR. 2009. "No limiar das 'artes'?-questões em torno da permeabilidade de fronteiras temporais e espaciais da arte rupestre de Trás-os-Montes Ocidental.” AQVAE FLAVIAE 41, pp. 45-92.

ALVES, L. BACELAR. 2013. "Monte de Góis, Caminha. Um santuário rupestre nas margens do rio Minho". En Bettencourt, A.M A Pré-História do Noroeste Português / The Prehistory of the North- Western Portugal, Territórios da Pré- História em Portugal. Vol. 2. Braga, pp. 169-183.

ALVES, L. BACELAR (2017). "Paisajes tatuados. Revaloración de la distribución del Arte Atlántico, métodos de investigación y cronología a la luz del hallazgo de un gran conjunto de arte rupestre en Monte Faro (Valença, Portugal).” Zephyrus, 8o(o), pp. 49-67. https://doi.org/10.14201/ zephyrus2017804967

ALVES, L. BACELAR.;REIS,M. 2017. “As gravuras rupestres do Monte Faro (Valença, Viana do Castelo) Um exemplo maior das Arte Atlântica peninsular.” En Portvgalia, Nova Série, 38, pp. 49-86. https://doi.org/10.21747/09714290/port38a2

ALVES, L. BACELAR; COMENDADOR REY, B. 2018. “Arte esquemático pintado en el noroeste peninsular: una visión integrada transfronteriza. Schematic Art paintings in north-western Iberia: an integrated view across borders." En Gallaecia: revista de arqueoloxía e antigüidade, 36, pp. 11-52. https://doi.org/10.15304/gall.36.5019

BARCIELA, P.; REY, E. 2000.Xacementos arqueolóxicos de Galicia. Xerais, Santiago de Compostela. BETTENCOURT, A. M. 2017. "Post-Palaeolithic rock art of north-western Portugal: An approach." In Recorded places, experienced places: the holocene rock art of the Iberian Atlantic north-west. BAR, Oxford, pp. 123-150.

BÓVEDA FERNÁNDEZ, M.J;CAÑIZO FRAGA, J.A.;VILASECO VÁZQUEZ, J.I.. 1999. "Lugares para grabar, lugares para morrer, petroglifos e cistas na Idade do Bronce do N.W. da Península Ibérica”. Gallaecia, 18, pp. 89-101

BRADLEY, R.;FÁBREGAS VALCARCE,R.; CRIADO BOADO, F. 1994-1995. "Arte rupestre y paisaje prehistórico en Galicia: Resultados del trabajo de campo entre 1992 y 1994.” Castrelos 7-8, pp. 67-95

BRADLEY, R. 1997. Rock art and the Prehistory of Atlantic Europe, Routledge, Londres.

BRADLEY, R. 2009. Image and Audience. Rethinking Prehistoric Art. Oxford University Press. Oxford.

CAMPOS GÓMEZ, J.C. 2018. Grabados rupestres de la provincia de León. Centro de estudios astorganos Marcelo Macías, Leon.

CARBALLO ARCEO, L. X.; FÁBREGAS VALCARCE, R.; LEDO BERNÁRDEZ, M.; CONSTELA DOCE, X. 1998. "Dos nuevos yacimientos con cerámica tipo Penha en el Valle del Miño". Zephyrus, 51, pp. $87-110$

CERNADAS SANDE, J. 2007. Gravados rupestres nos montes de Carnota. Santa Comba.

CRIADO BOADO, F.;FÁBREGAS VALCARCE, R.;SANTOS ESTÉVEZ, M. 2001. "Paisaje y representación en la Edad del Bronce : la descodificación del arte rupestre gallego”. En Ruiz-Gálvez Priego, M. (coord). La Edad del Bronce : ¿primera edad de oro de España? : Sociedad,economia e ideología. Barcelona, Critica Arqueología, pp 291-319

COMENDADOR, B.;GONZÁLEZ, F. 2017. "Rock art of the upper Támega Valley (Galicia, Spain).” In Recorded places, experienced places: the holocene rock art of the Iberian Atlantic north-west. BAR Publishing, Oxford, pp. 49-62.

COSTAS GOBERNA, F.J; HIDALGO CUÑARRO, J.M. (Coord.) 1998. Reflexiones sobre el arte rupestre prehistórico de Galicia. Vigo 
COSTAS GOBERNA, F.J; HIDALGO CUÑARRO, J.M. (Coord.) 2005. Arte rupestre prehistórica do Eixo Atlántico/Arte rupestre pré-histórica do Eixo Atlântico. Eixo Atlantico do Noroeste Peninsular, Vigo.

CURRAS REFOJOS, B. 2014. Transformaciones sociales y territoriales en el Baixo Miño entre la edad del hierro y la integración en el imperio romano. Tesis doctoral. dirigida por Pedro López Barja de Quiroga y Almudena Orejas Saco del Valle. Santiago de Compostela.

ENCINAS, J. M. V.; RODRÍGUEZ, C. F.; PRIETO, M. N. F. 2008. "Nuevos grabados rupestres al aire libre en los alrededores de la localidad de Lucillo (León).” Férvedes: Revista de investigación, 5 , p. 213.

FÁBREGAS VALCARCE, R.; MARTÍNEZ-CORTIZAS, A.; BLANCO CHAO, R.; CHESWORTH, W. 2003. "Environmental change and social dynamics in the Second-Third Millennium BCNW Iberia”, Journal of Archaeological Science 30 (7), pp. 859-871. https://doi.org/10.1016/So3054403(02)00264-9

FÁBREGAS VALCARCE, R. 2010. Os petróglifos e o seu contexto: un exemplo da Galicia meridional. Instituto de Estudios Vigueses, Vigo.

FÁBREGAS VALCARCE, R.;RODRÍGUEZ-RELLÁN, C. 2015. "Walking on the stones of years. Some remarks on the north-west Iberian rock art". En P. Skoglund, J. Ling \& U. Bertilsson (eds.): Picturing the Bronze Age. Swedish Rock Art Series 3, Oxbow Books, Oxford, pp. 47-63.

FÁBREGAS VALCARCE, R.; RODRÍGUEZ-RELLÁN; RODRÍGUEZ ÁLVAREZ, E. 2009. "Representacions de armas no interior de Galicia (Comarca de Deza, Pontevedra): Unha reflexion sobre a distribucion e cronoloxia destes motivos" Gallaecia, 28, pp. 49- 68.

FÁBREGAS VALCARCE,R.; RODRÍGUEZ RELLÁN,C (eds.). 2012. A arte rupestre no Norte do Barbanza. Andavira, Santiago de Compostela.

FERNÁNDEZ DE LA CIGOÑA NÚÑEZ, E. 2007. As neves: cruces, cruceiros e petos. Vigo. Asociación Galega para a Cultura e a Ecoloxía.

FERNÁNDEZ PINTOS, J. 1993. "Asociaciones de combinaciones circulares a equipos de molienda rupestres en el NO peninsular”, en Actas do VI Colóquio Portuense de Arqueologia. (Porto 1987), Porto, pp. 75-96.

FILGUEIRAS REY, A.; RODRÍGUEZ FERNÁNDEZ, T. 1994. “Túmulos y petroglifos. La construcción de un espacio funerario. Aproximación a sus implicaciones simbólicas. Estudio de la Galicia centro- oriental: Samos y Sarria”. Espacio, Tiempo y Forma, 7, pp. 211-253.

FREDELL, C.;KRISTIANSEN,K.; CRIADO, F. 2010. Representations and communications: creating an Archaeological Matrix of Late Prehistoric Rock Art. Oxford.

GARCÍA ALÉN, A.; FILGUEIRA VALVERDE, J. 1977. Inventario de monumentos megalíticos. Catalogación arqueológica y artística, Pontevedra.

GIL AGRA,L. ;CONCHEIRO COELLO, A. 1994. " Una nueva zona de arte rupestre al aire libre en el NW : la península de Barbanza”. Espacio, Tiempo y Forma, Serie I, Prehistoria y Arqueología 7, pp. 129-151.

GONZÁLEZ AGUIAR, B. 2011. "Grabados rupestres en el sur de la provincia de Lugo." Espacio Tiempo y Forma. Serie I, Prehistoria y Arqueología, 4, pp. 123-140. https://doi.org/10.5944/ etfi.4.2011.10748

GONZÁLEZ AGUIAR, B. 2019. Los grabados rupestres del suroeste de Lugo Análisis tecnológico. Tese de doutoramento. UNED.

GÓMEZ,A.; FÁBREGAS,R.; MÉNDEZ,D.; PAZ, M.S. 2004 • "Nuevos datos sobre cerámica Penha en el Sur de Galicia”. Sautola, 10, pp. 43-49.

INGOLD,T. 2000. The Perception of the Environment: Essays in livelihood, dwelling and skill. London.

LLOBERA, M. 1996. Exploring the topography of mind: GIS, social space and archaeology. Antiquity, 7o, pp. 612-622. https://doi.org/10.1017/Sooo3598Xo0083745

LÓPEZ CORDEIRO, M. 2010, "Prospección para o Estudo de Impacto Arqueolóxico da liña para interconexión do Parque Eólico das Neves, As Neves (Pontevedra)”, en Actuacións arqueolóxicas : ano 
2008 / coordinación, Paz Varela Campos. Santiago de Compostela: Xunta de Galicia, Dirección Xeral de Patrimonio Cultural, D.L.

MARTÍNEZ TAMUXE, X. 1982. "Riqueza rupestre en el monte de Torroso (A Guardia-O Rosal)” EMP, $X X X V I, p$ p. 243-251.

MARTÍNEZ TAMUXE, X; MARTÍNEZ BARBOSA, J. 2008. “Algúns gravados rupestres descubertos no concello das Neves. Parroquias de San Xoán de Rubiós, San Xosé e Santiago de Ribarteme” Soberosum, Revista de Estudos Museo Municipal de Ponteareas, $\mathrm{N}^{\circ} 3$.

MÉNDEZ QUINTAS, E. 2018. Memoria arqueolóxica. Limpeza, delimitación e rexistro gráfico do petróglifo da Coutada (Taboexa, As Neves). ED102A 2018/626-O.

MÉNDEZ-QUINTAS, E., SANTONJA, M., PÉREZ-GONZÁLEZ, A., DUVAL, M., DEMURO, M., ARNOLD, L.J., 2018. "First evidence of an extensive Acheulean large cutting tool accumulation in Europe from Porto Maior (Galicia, Spain)”, Scientific Reports 8, pp. 30-82. https://doi.org/10.1038/ S41598-018-21320-1

PEÑA SANTOS, A.; REY GARCÍA, J.M. 2001. Petroglifos de Galicia. A Coruña: Vía Láctea.

REY CASTIÑEIRA,J.;FRANCO FERNÁNDEZ,M.;EIROA GARCÍA, J.J. 2017. "The rock engravings of Cova da Bruxa (Galicia, north-west Iberia). A place of reiterated hunting scenes." En Bettencourt, Santos Estévez, Aluai Sampaio, Cardoso (Coord). Recorded places, experienced places: the holocene rock art of the Iberian Atlantic north-west. BAR Publishing, pp. 87-97.

RODRÍGUEZ RELLÁN, C.;FÁBREGAS VALCARCE, R.;VÁZQUEZ MARTÍNEZ, A. 2018. “Cifras e imágenes: una aproximación cuantitativa a los petroglifos gallegos / Figures and images: a quantitative approach to the petroglyphs of Galicia” . Trabajos de Prehistoria 75 (1), pp.109-127. https:// doi.org/10.3989/tp.2018.12206

RODRÍGUEZ RELLÁN, C.; FÁBREGAS VALCARCE, R. 2013.”Beyond the borders: some thoughts on Galician rock art”. En Sanches, M. J (coord) "1a Mesa-Redonda. Artes Rupestre da Pré-História e da Proto-História: paradigmas e metodologias de registo” Trabalhos de Arqueologia, 54, pp. 239-248.

RODRÍGUEZ RELLÁN, C.; FÁBREGAS VALCARCE, R. 2015 • "Arte rupestre galaica unha achega dende a estatística espacial e os SIX”. Semata: Ciencias sociais e humanidade, pp. 323-348.

RODRÍGUEZ RELLÁN, C.; GORGOSO LÓPEZ, L.; FÁBREGAS VALCARCE, R. 2008. “O conxunto de petróglifos de Campo da Uz (Sta. María de Areas, Antas de Ulla) e as vías de tránsito cara o interior lucense”. Gallaecia, 27, pp. 35-61.

SANTOS ESTÉVEZ, M. 2007. Petroglifos y paisaje social en la prehistoria reciente del noroeste de la península Ibérica. TAPA 38. CSIC, Santiago de Compostela.

SANTOS ESTÉVEZ, M.; BETTENCOURT, A. M. 2017. "O Conjunto de gravuras rupestres de Santo Adrião (Caminha, Portugal). Embarcações, armas, cavalos e ex-votos”. En Atas do Congresso dos Arqueólogos Portugueses. Lisboa 2017, pp. 1055-1070.

TILlEY, C. 1994. A phenomenology of landscape. Place, paths and monuments. Social change. Oxford, Berg.

PEREIRA MARTÍNEZ, X. 2017. Os gravados de fauna na Arte Rupestre Atlántica O caso do Baixo Miño e o norte de Portugal. Traballo de Fin de Mestrado. Universidade de Santiago de Compostela.

VÁZQUEZ MARTÍNEZ, A.; FÁBREGAS VALCARCE, R.; RODRÍGUEZ RELLÁN, C. 2016. "Going by the numbers: a quantitative approach to Galician prehistoric petroglyphs”, en Fábregas Valcarce,R. e Rodríguez Rellán,C. (eds.) Public images, private readings. Multi- perspective approaches to the Post-Palaeolithic rock art. Proceedings of the XVII UISPP World Congress (Burgos Spain 2014) 5, Session A11e, Archaeopress. Oxford, pp. 63-69.

VÁZQUEZ MARTÍNEZ, A; RODRÍGUEZ RELLÁN, C.; FÁBREGAS VALCARCE, R. 2018. "Petroglifos gallegos, una perspectiva desde el siglo XXI”, Rev. Cuad. De Art. Prehistoria. Num. 6. JulioDiciembre, pp. 61-83. 
VÁZQUEZ MARTÍNEZ, A. 2016. "Redescubrindo o arte rupestre ao aire libre no Rosal. (Pontevedra, Galicia)", en Estudos de Arqueoloxía, Prehistoria e Historia Antiga: Achegas dos novos investigadores, Arcian, Santiago de Compostela, pp. 43-55.

VILLOCH VÁZQUEZ, V. 1995 . "Monumentos y petroglifos:La construcción del espacio en las sociedades constructoras de túmulos del noroeste peninsular”. Trabajos de Prehistoria 52, nº ${ }^{0}$. pp 39-55. https://doi.org/10.3989/tp.1995.v52.11.430 